\title{
RADIOCARBON DETERMINATION OF PARTICULATE ORGANIC CARBON IN NON-TEMPERATED, ALPINE GLACIER ICE
}

\author{
Peter Steier ${ }^{1,2} \bullet$ Roswitha Drosg $^{1} \bullet$ Mariaelenea Fedi $^{3} \bullet$ Walter Kutschera ${ }^{1} \bullet$ Martin Schock $^{4} \bullet$ \\ Dietmar Wagenbach ${ }^{4}$ Eva Maria Wild ${ }^{1}$
}

\begin{abstract}
Dating ice samples from glaciers via radiocarbon is a challenge that requires systematic investigations. This work describes an approach for extraction and accelerator mass spectrometry (AMS) ${ }^{14} \mathrm{C}$ analysis of the particulate organic carbon (POC) fraction in glacier ice samples. Measurements were performed at VERA (Vienna Environmental Research Accelerator) on ice samples obtained mainly from the non-temperated ablation zone of the Grenzgletscher (Grenz Glacier) system (Monte Rosa Massif, Swiss Alps). The samples were obtained from 2 sampling sites situated roughly on a common flow line. The sample masses used were between 0.3 and $1.4 \mathrm{~kg}$ of ice, yielding between 18 and $307 \mu \mathrm{g}$ of carbon as POC. The carbon contamination introduced during sample processing varied between 5.4 and $33 \mu \mathrm{g} \mathrm{C}$ and originated mainly from the quartz filters and the rinsing liquids used in processing. Minimum sample sizes for successful graphitization of $\mathrm{CO}_{2}$ in our laboratory could be reduced to $<10 \mu \mathrm{g}$ carbon, with a background in the graphitization process of $\sim 0.5 \mu \mathrm{g}$ of 40 -pMC carbon. Evaluation of the whole procedure via 11 Grenzgletscher samples revealed a surprisingly large scatter of pMC values. We obtain a mean calibrated age of $2100 \mathrm{BC}$ to $\mathrm{AD} 900$ (95.4\% confidence level), which is not significantly different for the 2 sampling sites. Discussions of these results suggest that single ${ }^{14} \mathrm{C}$ dates of glacial POC are presently of limited significance. Future improvements with respect to analytical precision and sample characterization are proposed in order to fully explore the POC dating potential.
\end{abstract}

\section{INTRODUCTION}

Glaciers and ice sheets constitute an important archive of Earth's climatic and environmental history. Compared to other paleoarchives, glaciers and ice sheets are unique in providing proxy records related to climate parameters (e.g. stable water isotopes), as well as direct access to past atmospheric composition changes (e.g. greenhouse gases and atmospheric dust). Most investigations were performed on ice cores drilled in Greenland (e.g. GRIP and GISP2, Hammer et al. 1997) and Antarctica (e.g. Vostok, Petit et al. 1999; Dome C, EPICA Community Members 2004). In these high-latitude ice sheets, englacial temperatures are low enough to keep the isotopic and chemical ice composition "frozen" in time, whereas their large-scale geometry commonly ensures a smooth and approximately linear depth-age relationship over a substantial fraction of the total ice thickness. Thus, an appropriate chronology — which is the prime prerequisite for exploiting the climatological information - can be derived from stratigraphical investigations over several thousand years (Meese et al. 1997). Annual layer counting and oxygen isotopic stage correlation are the most important stratigraphical methods and have become standard tools for dating polar ice cores.

However, stratigraphical dating is not applicable to all ice archives, which include non-temperated mountain glaciers, rock glaciers, cave ice, cold ablation zones, and ice wedges. For example, nontemperated mountain glaciers, necessarily situated on the highest summit ranges, show relatively small glacier geometries. This leads to complex ice-flow patterns, extensive ice-thinning rates, and irregular snow deposition. These shortcomings commonly restrict useful stratigraphical dating to some $100 \mathrm{yr}$ at best (e.g. Thomson et al. 2002; Wagenbach 1989; Eisen et al. 2003). Thus, to extend the domain of long-term ice records to non-polar regions and to explore other promising ice archives, an alternative dating tool is urgently needed.

\footnotetext{
${ }^{1}$ Vienna Environmental Research Accelerator (VERA), Institut für Isotopenforschung und Kernphysik, Universität Wien, Währinger Straße 17, A-1090 Wien, Austria.

${ }^{2}$ Corresponding author. Email: peter.steier@univie.ac.at.

${ }^{3}$ Dipartimento di Fisica dell'Università di Firenze and INFN Sezione di Firenze, via Sansone 1, 50019 Sesto Fiorentino (Fi), Italy.

${ }^{4}$ Institut für Umweltphysik, Universität Heidelberg, Im Neuheimer Feld 229, 69120 Heidelberg, Germany.
} 
Radiocarbon analysis is the most precise tool for dating organic matter remains throughout the Holocene. Organic matter is deployed in stratified archives like lake sediments or peat bogs (e.g. Goslar et al. 2005). Provided that the organic carbon entrapped in glacier bodies is representative for the deposition age, ${ }^{14} \mathrm{C}$ dating is expected to be useful for these kinds of archives as well. Organic microfossils like moss (Haeberli et al. 1999) or insect remains (Thompson et al. 1998) found by chance in ice cores have already been used. However, only small amounts of organic carbon are commonly contained in glacier ice, either entrapped as trace gases in air bubbles or preserved as aerosol-related species in the ice matrix. The organic carbon fractions may be divided into POC (particulate organic carbon) and DOC (dissolved organic carbon), which are distinguished using a pore filter of typically $0.4 \mu \mathrm{m}$ pore size.

Inorganic $\mathrm{CO}_{2}$ eventually trapped in air bubbles below the firn-ice transition is a less suitable ${ }^{14} \mathrm{C}$ dating target since it may contain a substantial contribution of in situ-produced ${ }^{14} \mathrm{C}$ (mainly via spallation of oxygen in the ice by energetic cosmic ray neutrons, Lal et al. 1990; Lal et al. 2000; Lal et al. 2001; Van Roijen et al. 1995). This is especially true for mountain drill sites, where the in situ contribution is enhanced due to high altitudes and low accumulation rates.

In this work, we explore the potential of ${ }^{14} \mathrm{C}$ dating the POC fraction of glacier ice. Intending to develop an appropriate procedure, we focused on ice-block samples collected in the non-temperated ablation zone, a polythermal valley glacier in the Alps. This approach offers samples of large volume at reasonable effort for testing and evaluation of the method. Various cold ice bodies from lower altitude, as well as ice-sheet margins, may also present an important future application (e.g. Reeh et al. 1991) of this dating tool.

\section{METHODS}

Figure 1 shows the Monte Rosa Massif, Switzerland. The samples were taken from glacier ice from the part of Gornergletscher (Gorner Glacier) that originates from the Grenzgletscher (Grenz Glacier) system and flows down the northwesterly flank of the Monte Rosa Massif (Renaud 1952). The uppermost catchment area of the polythermal Grenzgletscher is non-temperated, which is also the case for a substantial part of its lower ablation zone. Here the cold ice reemerges at the surface at englacial temperatures significantly below the melting point (Haeberli 1975), which generally ensures the integrity of the ice since deposition in the accumulation zone. Surface sampling of ice blocks was performed at 2 positions on the tongue of Gornergletscher that were situated roughly on a common flow line of the emerging Grenzgletscher material. The sites are about $1500 \mathrm{~m}$ apart and situated at an altitude of about 2550 and $2510 \mathrm{~m}$ asl, respectively. The typical ice flow and the glacier geometry suggest that the ice at these sampling sites should be at least a hundred years old. Indeed, ${ }^{210} \mathrm{~Pb}$ analyses at the Institut für Umweltphysik, Heidelberg, on ice blocks from both sites were close to the analytical background, showing that the ice is older than $\sim 150 \mathrm{yr}$. This age constraint was corroborated by analyses of the (partly anthropogenic) sulfate, ammonium, and nitrate ions, clearly indicating preindustrial levels. We expected that ice from the lower site should be systematically older compared to the upper one. However, assuming a depth-averaged downslope ice velocity of about $10 \mathrm{~m} / \mathrm{yr}$ at the sampling sites, the expected age difference would be only on the order of $100 \mathrm{yr}$, which can hardly be resolved by the applied ${ }^{14} \mathrm{C}$ method. In addition to the Gornergletscher ice samples, surface snow was collected from the highest accumulation zone of Grenzgletscher (Colle Gnifetti, $4450 \mathrm{~m}$ asl), serving as the modern (bomb- ${ }^{14} \mathrm{C}$ influenced) counterpart.

All samples were shipped in a frozen state and stored at $-23{ }^{\circ} \mathrm{C}$ at the University of Heidelberg. Here the ice blocks were cut into suitable pieces of $\sim 500-1000 \mathrm{~g}$ in a dust-free cold room, wrapped in alu- 


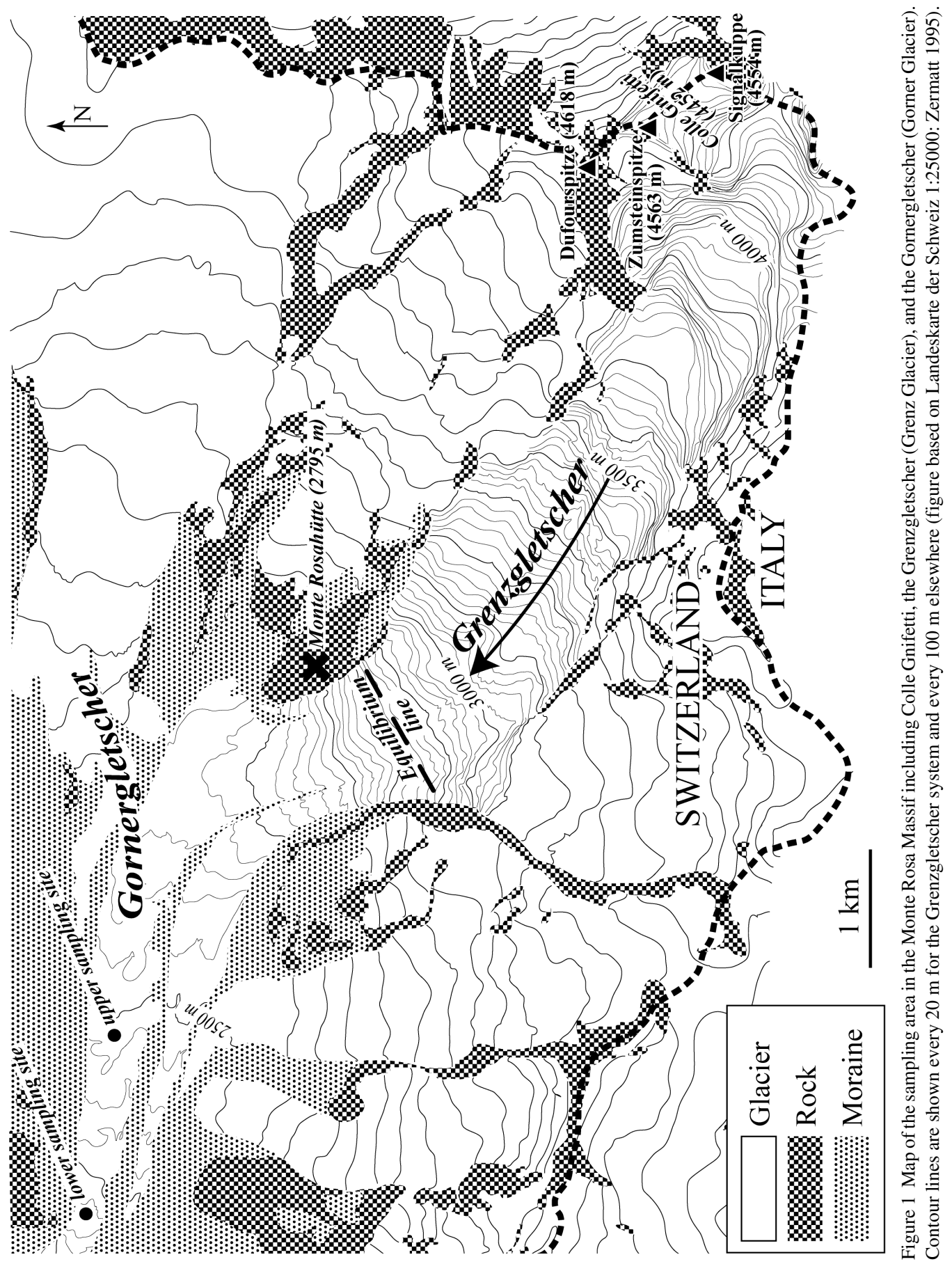


minum foil, and sealed in polyethylene bags. After shipment to the University of Vienna, the blocks were kept in a freezer at about $-15^{\circ} \mathrm{C}$.

Preindustrial atmospheric POC is mainly composed of biogenic particles (such as pollen, bacteria, spores, etc.), leaf fragments, the organic fraction of soil dust, and products of biomass burning like elemental carbon (EC). Secondary organic aerosol, as derived from gas-to-particle reactions (Seinfeld 1998) of volatile biogenic precursors, are thought to be mainly water soluble and thus may not substantially contribute to the filterable POC contained in meltwater samples. There is no need to separate the major POC fractions (e.g. organic carbon [OC] and elemental carbon [EC]) as done for modern atmospheric aerosol (e.g. Szidat et al. 2004). In preindustrial ice, we expect that all POC fractions yield ${ }^{14} \mathrm{C}$ ages correlated to the time of ice formation. Deviations from this assumption are a principal limitation of the method and are discussed below.

Two methods have been used by other groups to extract POC from ice samples: filtering of meltwater (Chýlek et al. 1987) and sublimating the ice sample in a vacuum while depositing the particles onto a surface substrate (Biegalski et al. 1998). Sublimation may provide a better particle recovery yield and would collect a part of the DOC fraction as well, but the meltwater is unavoidably lost. We have chosen to develop a filtration method. If one considers rare and small ice samples from remote drill sites, this method may allow us to extract the POC of the complete sample without interfering with further measurements on the meltwater itself (including separate DOC analyses). Additionally, filtration allows us to handle large samples in a relatively short time. The VERA Laboratory was already involved in ${ }^{14} \mathrm{C}$ measurements of snow (Weissenbök et al. 2000), but not in preparing the samples. Thus, we had to customize an appropriate filtration procedure, whereas only minor experimental changes were required in the accelerator mass spectrometry (AMS) target preparation and measurement procedures.

The overall carbon content is as low as a few dozen $\mu \mathrm{g}$ per $\mathrm{kg}$ of ice; thus, care has to be taken to control the contamination introduced during sample preparation. Since ambient dust imposes a substantial problem, the critical steps during handling of the ice and the POC filters were performed in a laminar-flow box (nominally class 100). Materials used in the setup are (almost exclusively) made of quartz, glass, stainless steel, and PTFE or PFA. Teflon ${ }^{\circledR}$ tubing is expected to prevent particles from sticking to the tube walls. Parts and tools are cleaned in an ultrasonic bath; residual surface dust was blown off with clean $\mathrm{N}_{2}$. Materials that withstand high temperatures (quartz filters, quartz vials, and copper oxide for the combustion, see below) were heated shortly before use at $950{ }^{\circ} \mathrm{C}$ for $4 \mathrm{hr}$. Still hot $\left(\sim 500^{\circ} \mathrm{C}\right)$, they were put into a container with saturated $\mathrm{H}_{2} \mathrm{O}$ atmosphere. This procedure should reduce readsorption of carbon-containing trace gases from laboratory air.

The central part of the melting apparatus (see Figure 2) consists of a double-walled glass vessel, where warm water flowing through the double walls allows the melting rate to be controlled. At a water temperature of $\sim 30^{\circ} \mathrm{C}$ (measured at the exit), a sample melts in $\sim 1 \mathrm{hr}$. All tubes leading into the melting unit are equipped with protective dust filters, ensuring that all liquids and gases entering the melting unit are dust free. During operation, the melting unit is partially submerged in an ultrasonic bath, including the port used as the meltwater outlet at the lowest point. The purpose of the ultrasonic bath is to prevent insoluble particles from sticking to the glass walls of the melting container.

Before melting, the ice sample is put into a Styrofoam ${ }^{\mathrm{TM}}$ box where it slowly warms up to $0{ }^{\circ} \mathrm{C}$. Large temperature gradients at the sample surface could cause stress-induced microcracks, allowing meltwater from the potentially contaminated surface to migrate into the clean, inner part of the ice body. 


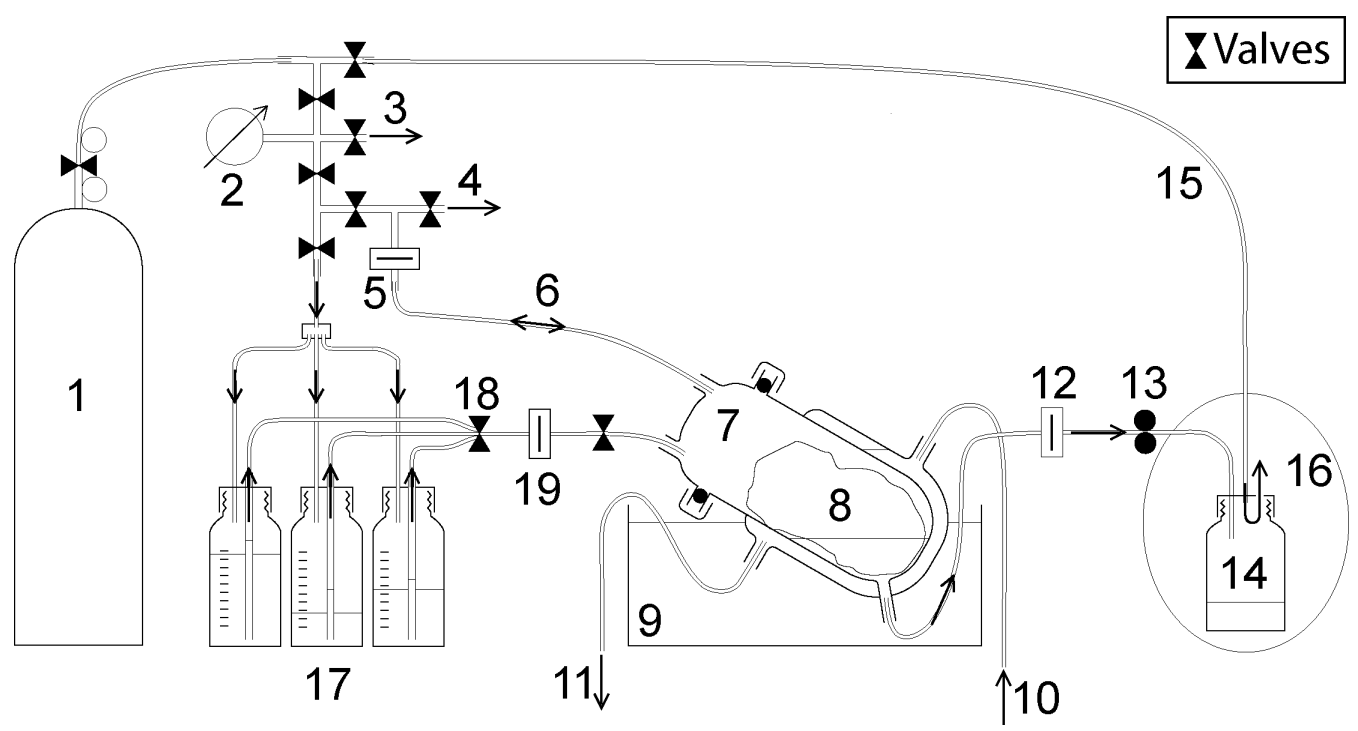

Figure 2 Schematic layout of the apparatus for ice melting and subsequent collection of POC on a particle filter: 1) $\mathrm{N}_{2}$ bottle; 2) pressure gauge; 3) pressure exhaust; 4) pressure release valve for melting container; 5) filter for gas; 6) $\mathrm{N}_{2}$ pressure supply/release pipe; 7) melting container; 8) ice sample; 9) ultrasonic bath; 10,11) warm water in and out; 12) POC sample filter; 13) hose clamp; 14) bottle for meltwater sample; 15) $\mathrm{N}_{2}$ supply for meltwater bottle/glove bag; 16) glove bag; 17) transfer flask for rinsing liquids; 18) manifold valve; 19) filter for rinsing liquids. The arrows indicate the flow direction. See text for operational procedure.

The melting unit is taken into the laminar flow box for sample loading with tubings closed. Melting and filtration are done under overpressure with clean $\mathrm{N}_{2}$. This procedure protects the meltwater from contamination with laboratory air, which will be essential for future measurements of the DOC fraction.

The sample filter holder is made of stainless steel and Teflon with a stainless steel frit supporting the quartz fiber filter (Sartorius QMF, $85 \mathrm{~g} / \mathrm{m}^{2}$, binder-free, $25 \mathrm{~mm}$ diameter, later-cut down to $12 \mathrm{~mm}$ ). The filter was mounted only after disposal of the first $\sim 100 \mathrm{~mL}$ of sample water, in order to eliminate surface contamination. A filtration rate of typically $\sim 0.2 \mathrm{~mL} / \mathrm{sec}$ was maintained and controlled by the $\mathrm{N}_{2}$ overpressure (400-1000 mbar) and by a hose clamp at the sample filter outlet. Filtration of accumulated meltwater was done at intervals, with the ultrasonic bath switched off in between steps. The meltwater was not pushed out completely, since gas bubbles inside the filter holder require a strong pressure increase to start the filtration process again. For possible subsequent analyses, the filtrate can be collected in a glass bottle inside a glove bag filled with clean $\mathrm{N}_{2}$.

After complete melting of the ice sample, the apparatus is rinsed with $\sim 50 \mathrm{~mL} 1 \mathrm{M} \mathrm{HCl}$, which is transferred from a flask by $\mathrm{N}_{2}$ overpressure through a combination of several filters into the melting unit. In the final procedure, we used a combination of a glass frit, a quartz filter (similar to the POC sample filter), and a polycarbonate membrane filter (pore size $0.22 \mu \mathrm{m}$, Poretics). The melting unit filled with the rinsing liquid is thoroughly shaken. The ultrasonic bath is switched on for 5 min to mobilize particles sticking to the walls, and the rinsing liquid is drained also through the POC filter. By using $\mathrm{HCl}$ in the first rinsing, we expect complete removal of carbonate particles. Rinsing is repeated twice using $\sim 50 \mathrm{~mL} \mathrm{H}_{2} \mathrm{O}$ bidest. 
Before each use, the melting unit is cleaned and a process blank is taken. Cleaning of the melting apparatus is done similarly to the rinsing after ice melting (except that no sample filter is attached), with $\sim 200 \mathrm{~mL} 0.7 \mathrm{M} \mathrm{HNO}_{3}$ and 2 rinses with $\sim 100 \mathrm{~mL} \mathrm{H}_{2} \mathrm{O}$ bidest. A process blank is prepared for each sample using the same amount of rinsing liquids that is used afterwards for the corresponding ice sample. Table 1 shows the results for the process blanks actually used for blank correction. Here, as in the following, we characterize the ${ }^{14} \mathrm{C}$ content by pMC values (percent Modern Carbon), as defined by Stuiver and Polach (1977).

Table 1 Summary of ${ }^{14} \mathrm{C}$ measurements on process blanks.

\begin{tabular}{|c|c|c|c|c|c|}
\hline $\begin{array}{l}\text { Label of } \\
\text { process blank }\end{array}$ & $\begin{array}{l}\text { Corresponding } \\
\text { ice sample }\end{array}$ & $\begin{array}{l}\text { Eff. filter } \\
\text { diameter } \\
(\mathrm{mm})\end{array}$ & $\begin{array}{l}\text { Rinsing liquids } \\
(\mathrm{mL})\end{array}$ & $\begin{array}{l}\mathrm{M}_{\text {blank,meas }} \\
(\mu \mathrm{g} \text { carbon) }\end{array}$ & $\begin{array}{l}\mathrm{pMC}_{\text {blank,meas }} \\
(\%)\end{array}$ \\
\hline HD51 & HD44 & 25 & 300 & 8.6 & $65.8 \pm 1.0$ \\
\hline HD54 & HD56 & 25 & 340 & 32.4 & $77.7 \pm 0.7$ \\
\hline HD58 & HD59 & 25 & 400 & 10.7 & $119.2 \pm 1.4$ \\
\hline HD63 & HD60 & 25 & 400 & 11.0 & $103.1 \pm 1.4$ \\
\hline M25 & M26 & 25 & 150 & 17.3 & $78.1 \pm 0.9$ \\
\hline \multicolumn{4}{|c|}{ Average of $25-\mathrm{mm}$ filters } & \multicolumn{2}{|l|}{$16.0 \pm 9.7^{\mathrm{a}}$} \\
\hline M8 & M9 & 8 & 150 & 6.0 & $85.5 \pm 2.2$ \\
\hline M10 & M11 & 8 & 150 & 5.4 & $72.4 \pm 2.6$ \\
\hline M12 & M13 & 8 & 150 & 6.2 & $102.1 \pm 3.0$ \\
\hline M14 & M15 & 8 & 150 & 7.5 & $80.3 \pm 2.2$ \\
\hline M23 & M24 & 8 & 150 & 8.7 & $71.0 \pm 1.7$ \\
\hline M21 & M22 & 8 & 150 & 6.2 & $77.8 \pm 3.7$ \\
\hline M18 & M19 & 8 & 150 & 7.8 & $89.7 \pm 3.2$ \\
\hline \multicolumn{4}{|c|}{ Average of 8-mm filters } & \multicolumn{2}{|l|}{$6.8 \pm 1.2^{\mathrm{a}}$} \\
\hline \multicolumn{5}{|c|}{ Overall average } & $85.2 \pm 15.7^{a}$ \\
\hline
\end{tabular}

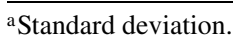

The filtration procedure was slightly different for the first 2 Gornergletscher samples from each site. For these, $100 \mathrm{~mL}$ of $\mathrm{HCl}(0.1 \mathrm{M})$ and $2 \times 100 \mathrm{~mL}$ of $\mathrm{H}_{2} \mathrm{O}$ bidest were used for rinsing; the quartz filters for the POC samples were $25 \mathrm{~mm}$ in diameter. The amount of carbon collected on the process blanks is variable in both amount and ${ }^{14} \mathrm{C}$ content. The investigations performed thus far do not yet prove a clear correlation between the contamination and the amount of filtrated liquids. To assess and possibly improve the quality of the rinsing liquids remains one methodical focus for the future. For the present experiments, we reduced the total amount of rinsing liquids down to the smallest amount that can be reliably handled by the present setup $(150 \mathrm{~mL})$. Another possible source of contamination is represented by the quartz filter itself. From unused, wetted filters, typically $3 \mu \mathrm{g}$ of carbon were extracted. Thus, we decided to reduce the filter diameter to $12 \mathrm{~mm}$. We also cut off the "unused" margin of the filter after the filtration, yielding an effective diameter of $8 \mathrm{~mm}$.

By these means, the typical background fell to $\sim 7 \mu \mathrm{g} \mathrm{C}$. The disadvantage is, however, the reduction of the active filtration surface. For some very "dirty" ice samples, the 12 -mm filters were completely blocked after a small amount of meltwater ( $175 \mathrm{~mL}$ in one case) was passed through, so the remaining sample had to be discarded without filtration. (We stopped filtration when the rate had decreased 
down to $0.5 \mathrm{~mL} / \mathrm{min}$ at a nitrogen pressure of $1000 \mathrm{mbar}$.) Samples from the lower site show generally higher POC values. Thus, we decided to process the last sample of this batch (M26) again with a larger filter ( $25 \mathrm{~mm}$ diameter). With the larger filter, we introduced a higher carbon background. However, since the amount of collected POC was also higher in this case, the larger filter background did not pose a significant problem.

The still-wet filter is then placed in a quartz vial together with $500 \mathrm{mg}$ pretreated copper oxide (Merck, p.a., wire $0.65 \mathrm{~mm} \times 3 \mathrm{~mm}$ ) to provide oxygen during sample combustion, and with a small piece of silver wire to bind sulfur and halogens. The filled vial is evacuated and heated for $\sim 1 \mathrm{hr}$ to $\sim 130^{\circ} \mathrm{C}$ to remove moisture and volatile carbon compounds before flame-sealing. Subsequently, the POC sample is combusted to $\mathrm{CO}_{2}$ for $4 \mathrm{hr}$ at $950{ }^{\circ} \mathrm{C}$. After cooling down inside the oven, the samples are ready for graphitization. Systematic investigations revealed that the copper oxide contributes $<1 \mu \mathrm{g}$ to the carbon contamination (compare Vandeputte et al. 1998).

As opposed to previous work by Weissenbök et al. (2000), graphitization of the sample $\mathrm{CO}_{2}$ to graphite is now done in the VERA Laboratory. The method used mainly follows Vogel et al. (1984). We have modified the small-sample graphitization unit (reactor volume $2.6 \pm 0.2 \mathrm{~cm}^{3}$ ) previously used at VERA for ${ }^{14} \mathrm{CO}$ measurements in atmospheric air (Rom et al. 2000) for our needs (Figure 3).

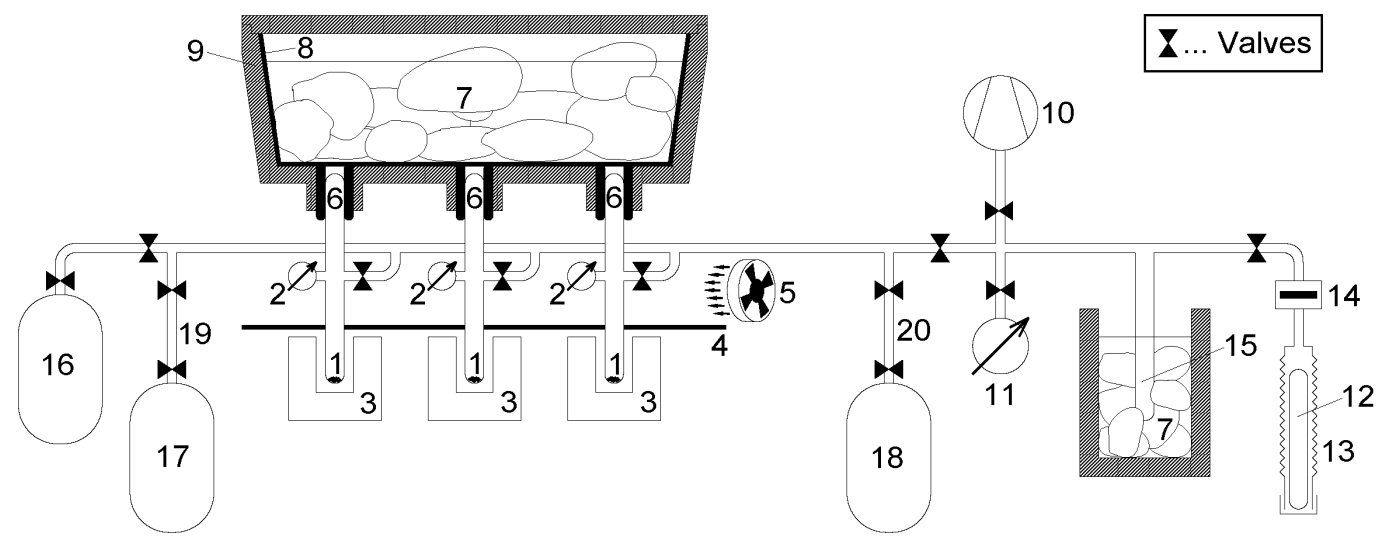

Figure 3 Schematic layout of the graphitization unit for small $\mathrm{CO}_{2}$ samples: 1) reaction vial with Fe catalyst (volume: 2.6 $\pm 0.2 \mathrm{~cm}^{3}$ ); 2) pressure sensor; 3) removable furnace; 4) copper heat shield; 5) blower; 6) water trap; 7) isopropanol-dryice mixture; 8) copper tray with cold fingers; 9) Styrofoam insulation; 10) turbomolecular pump; 11) Pirani pressure gauge; 12) $\mathrm{CO}_{2}$ sample vial; 13) tube cracker; 14) particle filter; 15) water trap; 16) $\mathrm{H}_{2}$ bottle; 17) "dead" $\mathrm{CO}_{2}$; 18) IAEA C-3 $\mathrm{CO}_{2}$; 19,20 ) buffer volumes-evacuated during sample $\mathrm{CO}_{2}$ transfer.

The graphitization unit now works semi-automatically, with most valves controlled by a computer program. This makes operation easier, and we think that the inherent reproducibility of computer control improves the measurement precision. Very small pressure sensors (Type PX72-015AV by Omega) are used to monitor the pressure in the reactors. For the low $\mathrm{CO}_{2}$ pressures encountered for our samples $\left(1.3 \mu \mathrm{g} \mathrm{C}=1 \mathrm{mbar}^{\mathrm{C}} \mathrm{CO}_{2}\right)$, these sensors show significant drifts, since they are not perfectly temperature compensated. Therefore, an air-cooled copper heat shield was mounted to insulate the pressure sensors from the hot reaction volume. By calibrating the pressure sensor immediately before graphitization, a precision of the pressure readings better than \pm 0.3 mbar is achieved. The pretreatment of the iron catalyst by heating in vacuum now takes place at $610^{\circ} \mathrm{C}$ (same as the graphitization temperature). In this step, the copper heat shield is removed, and the complete reactor 
assembly heats up to $\sim 50-60{ }^{\circ} \mathrm{C}$. This improves the cleaning by out-gassing. The Viton ${ }^{\circledR}$ O-rings previously used for the reactor chambers were replaced by Teflon gaskets, for which we observe less out-gassing at high temperatures. A Pirani gauge connected to the central manifold allows us to detect leaks easily.

Systematic investigations were performed to test the graphitization unit. The standard material used was $\mathrm{CO}_{2}$ from a bulk combustion of $13 \mathrm{~g}$ IAEA C-3 cellulose reference material of $129.41 \pm 0.06$ pMC (Rozanski et al. 1992). As blank material, we used commercially available "dead" $\mathrm{CO}_{2}$ (Linde, purity $>99.9993 \mathrm{Vol} \%$ ) from a Hungarian mineral spring (Rom et al. 2000). Graphitizations were performed for $\mathrm{CO}_{2}$ amounts corresponding to $4.0,6.5,13,39,130$, and $390 \mu \mathrm{g} \mathrm{C}$. The respective ${ }^{14} \mathrm{C}$ measurement results (Figure 4) allow us to estimate the amount of carbon contamination and its pMC by non-linear regression analysis. The simple mixing model fitted simultaneously to all 21 measurements on dead and C-3 carbon is

$$
\begin{gathered}
p M C_{\text {dead, meas }}=\frac{p M C_{\text {cont }} M_{\text {cont }}}{M_{\text {dead, meas }}}, \\
p M C_{C-3, \text { meas }}=\frac{129.41\left(M_{C-3, \text { meas }}-M_{\text {cont }}\right)+p M C_{\text {cont }} M_{\text {cont }}}{M_{C-3, \text { meas }}}
\end{gathered}
$$

where $M_{\text {cont }}$ is mass of the carbon contamination; $p M C_{\text {cont }}$ is $\mathrm{pMC}$ of the carbon contamination; $M_{\text {dead, meas }}, M_{C-3, \text { meas }}$ are the carbon mass of dead $\mathrm{CO}_{2}$ and C-3 $\mathrm{CO}_{2}$, respectively, calculated from the measured $\mathrm{CO}_{2}$ pressure; $p M C_{\text {dead,meas }}, p M C_{C-3, \text { meas }}$ are the measured $\mathrm{pMC}$ of the dead $\mathrm{CO}_{2}$ and the $\mathrm{C}-3 \mathrm{CO}_{2}$, respectively; and 129.41 is the nominal pMC value of the $\mathrm{C}-3$ material.

The fit yields an average total contamination of $M_{\text {cont }}=0.5 \pm 0.1 \mu \mathrm{g}$ carbon with a pMC value of 43 \pm 16 in the graphitization and AMS measurement.

We use between 0.6 and $3.0 \mathrm{mg}$ of iron (Merck, p.a., grain size $10 \mu \mathrm{m}$, produced by reduction) as a catalyst, leading to very low $\mathrm{C}: \mathrm{Fe}$ ratios for our small samples. We observe no significant influence of the amount of iron on the reaction rate, which mainly depends on the amount of sample $\mathrm{CO}_{2}$. Larger grain size of the iron results in slower graphitization: with $10-\mu \mathrm{m}$ grain size, the duration of the reactions was between 1 and $4 \mathrm{hr}$. These systematic measurements also reveal that the amount of modern carbon contamination increases with the amount of iron used. This result is in agreement with Vandeputte et al. (1998). In future experiments, we will minimize this background contribution by using the smallest iron quantity possible.

When the graphitization reaction is complete, the computer program initiates the pumping off of excess $\mathrm{H}_{2}$ and the heater switches off. The cold traps warm up and the water vapor comes in contact with the fresh graphite. By these means, we intend to deactivate the reactive surface to reduce adhesion of ambient carbon, but we have not yet investigated this systematically. The mixture of iron powder and graphite is pressed into aluminum sample holders suited for our ion source.

The ${ }^{14} \mathrm{C}$ measurements were performed at the VERA AMS facility following routine procedures (Steier et al. 2004). Changes required for small samples are as follows: i) the stable-isotope beams ${ }^{(12} \mathrm{C}^{-}$and $\left.{ }^{13} \mathrm{C}^{-}\right)$are injected for a longer time and ii) the sensitivities of the beam current amplifiers are adjusted for each sample automatically. Successful measurements were performed for carbon sample masses down to $\sim 10 \mu \mathrm{g}$. 

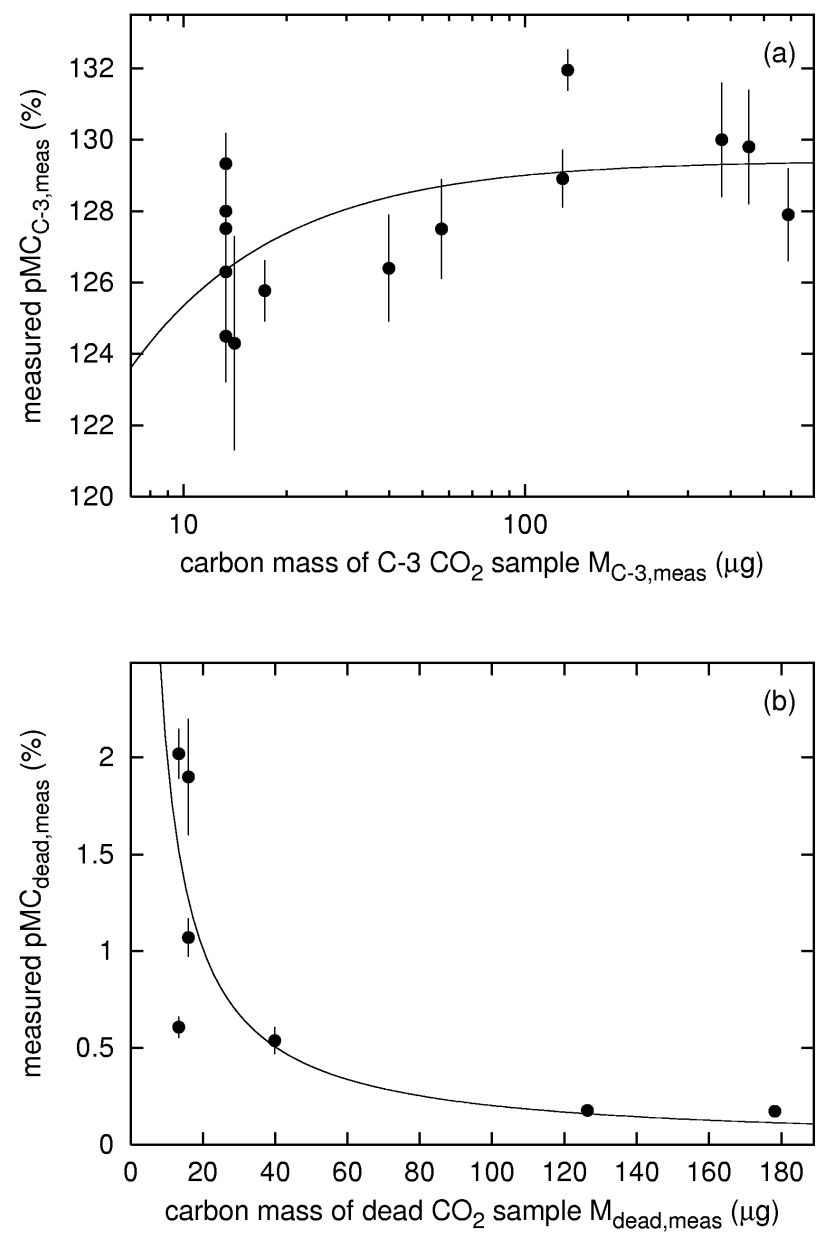

Figure 4 Contamination during $\mathrm{CO}_{2}$ graphitization and AMS measurements. Measured pMC values for a) IAEA C- $3 \mathrm{CO}_{2}$ and b) dead $\mathrm{CO}_{2}$ are plotted versus carbon mass of processed $\mathrm{CO}_{2}$. Note that contamination with unknown pMC leads for small standard amounts to measured $\mathrm{pMC}$ values that are too low (a). For small blanks, the measured pMC values are too high (b). The curves shown are model fits that allow one to assess the carbon contamination.

To investigate the dependency of the ionization yield on the sample size, we looked at the temporal development of the ${ }^{12} \mathrm{C}^{3+}$ currents during the AMS measurement (see Figure 5). We achieved a total detection efficiency of $2 \%$, calculated from the number of ${ }^{12} \mathrm{C}^{3+}$ ions in the Faraday cup integrated over the measurement time, divided by the number of $\mathrm{C}$ atoms in the sample $\mathrm{CO}_{2}$. The efficiency is independent of the sample size, and the same value can be assumed for ${ }^{14} \mathrm{C}$. Included in the observed efficiency value are the yield of the graphitization, the negative ion yield in the source, the stripping yield from $\mathrm{C}^{-}$to $\mathrm{C}^{3+}(0.50 \pm 0.02)$, and the duty factor for ${ }^{14} \mathrm{C}$ counting $(\sim 0.8)$. For some very small test samples, we observed currents that were exceptionally low (boxed data points in Figure 5). The reason is not yet understood and will be further investigated. None of the true ice samples and their corresponding process blanks were affected. 


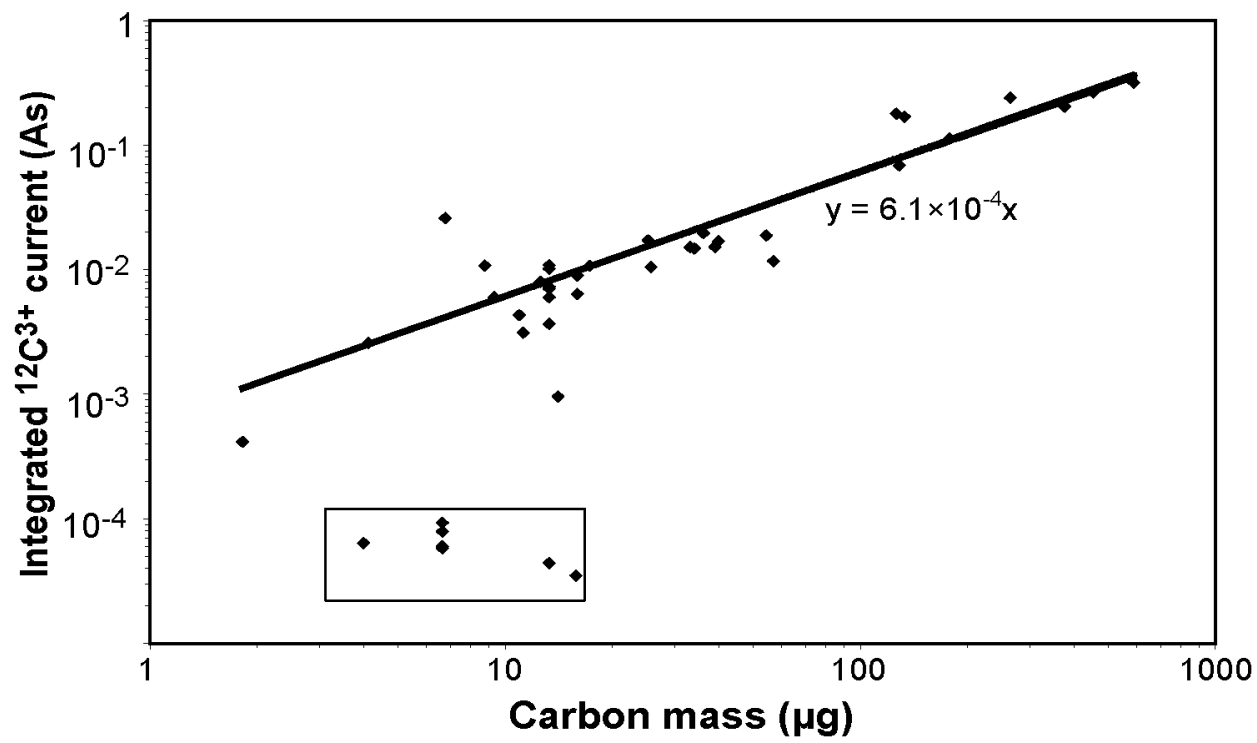

Figure 5 Indication of the analytical sensitivity of graphitization and AMS measurement. The integrated ${ }^{12} \mathrm{C}^{3+}$ current is shown for all completely sputtered samples versus the carbon mass calculated from the $\mathrm{CO}_{2}$ pressure before graphitization. The slope of the linear fit corresponds to a total detection efficiency of $2.1 \%$. The deviating data points in the box are discussed in the text.

\section{RESULTS}

Up to now, a total of $12{ }^{14} \mathrm{C}$ measurements on POC in glacier ice or snow have been performed. Table 2 lists the results.

Despite the fact that a separate process blank was prepared for each sample, we decided to use average values for the blank correction. As $p M C_{\text {blank,meas }}$, we used the average of all process blanks, whereas $M_{\text {blank,meas }}$ was the average of all process blanks prepared with the same filter size. For the 7 corresponding blank filters of $12 \mathrm{~mm}$ diameter processed so far, we observed a mean carbon contamination of $6.8 \mu \mathrm{g} \mathrm{C}$ with a standard deviation of $1.2 \mu \mathrm{g} \mathrm{C}$ (Table 1). The 5 blanks with $25-\mathrm{mm}$ filters, which were partly performed with preliminary versions of the preparation procedure, vary between 8 and $32 \mu \mathrm{g} \mathrm{C}$ (average $16.0 \mu \mathrm{g} \mathrm{C}$ with $9.7 \mu \mathrm{g} \mathrm{C}$ standard deviation). The average of all 12 blanks is $85 \mathrm{pMC}$ with a standard deviation of $16 \mathrm{pMC}$. A simple mixing model for sample carbon and contamination is applied:

$$
p M C_{\text {sample, } \text { corr }}=\frac{p M C_{\text {sample, meas }} M_{\text {sample, } \text { meas }}-p M C_{\text {blank, meas }} M_{\text {blank }, \text { meas }}}{M_{\text {sample, } \text { meas }}-M_{\text {blank, meas }}}
$$

where $p M C_{\text {sample,corr }}$ is the blank-corrected $\mathrm{pMC}$ value of the sample; $p M C_{\text {sample,meas }}, p M C_{\text {blank,meas }}$ are the measured $\mathrm{pMC}$ of sample and process blank, respectively; and $M_{\text {sample, meas }}, M_{\text {blank,meas }}$ are the measured carbon mass of sample and process blank, respectively.

Error propagation yields uncertainties of typically $\pm 1 \mathrm{pMC}$ for the blank-corrected sample values.

The surface snow sample HD60 taken in August 2000 at Colle Gnifetti shows a pMC value significantly higher than the respective pMC level in atmospheric $\mathrm{CO}_{2}$ (Levin and Hesshaimer 2000). Similar results have been reported by Weissenbök et al. (2000) and Biegalski et al. (1998) for POC of 
Table 2 Results of ${ }^{14} \mathrm{C}$ measurements of POC in glacier ice obtained from the ablation zone of Grenzgletscher and from snow at the highest point of the glacier (Colle Gnifetti). All uncertainties are given at $1 \sigma$.

\begin{tabular}{|c|c|c|c|c|}
\hline Sample nr & $\begin{array}{l}\text { Meltwater } \\
(\mathrm{mL})\end{array}$ & $\begin{array}{l}M_{\text {sample,meas }} \\
\text { ( } \mu \text { g carbon) }\end{array}$ & $\begin{array}{l}\mathrm{pMC}_{\text {sample,meas }} \\
(\%)\end{array}$ & $\begin{array}{l}\mathrm{pMC}_{\text {sample,corr }} \\
(\%)\end{array}$ \\
\hline \multicolumn{5}{|c|}{ Ice from ablation zone, lower sampling site } \\
\hline HD44 & $\sim 400$ & 35.4 & $71.7 \pm 0.8$ & $60.5 \pm 14.0$ \\
\hline HD56 & 700 & 206.9 & $100.8 \pm 0.5$ & $102.1 \pm 1.2$ \\
\hline M19 & 250 & 52.9 & $63.0 \pm 1.2$ & $59.7 \pm 1.5$ \\
\hline M22 & 175 & 58.4 & $75.3 \pm 0.6$ & $73.9 \pm 0.7$ \\
\hline M24 & 100 & 97.5 & $88.4 \pm 0.8$ & $83.3 \pm 0.9$ \\
\hline M26 & 500 & 184 & $78.1 \pm 0.9$ & $75.2 \pm 0.8$ \\
\hline \multicolumn{5}{|c|}{ Ice from ablation zone, upper sampling site } \\
\hline HD59 & 580 & 38.1 & $89.8 \pm 0.7$ & $89.8 \pm 6.6$ \\
\hline M9 & 970 & 45.7 & $70.5 \pm 0.9$ & $67.9 \pm 1.2$ \\
\hline M11 & 420 & 31.3 & $74.6 \pm 0.9$ & $71.7 \pm 1.4$ \\
\hline M13 & 770 & 18.5 & $59.4 \pm 1.1$ & $44.2 \pm 4.6$ \\
\hline M15 & 845 & 28.9 & $80.1 \pm 1.0$ & $78.6 \pm 1.3$ \\
\hline \multicolumn{5}{|c|}{ Snow from Colle Gnifetti } \\
\hline HD60 & 500 & 307 & $117.8 \pm 0.6$ & $119.6 \pm 1.4$ \\
\hline
\end{tabular}

recent snow samples. Our measured value of $119.6 \mathrm{pMC}$ corresponds to atmospheric ${ }^{14} \mathrm{CO}_{2}$ levels from $\sim 1985$. However, a straightforward transformation into a sample age is not possible for modern POC, since an unknown amount of particles from fossil fuel combustion will have diluted the ${ }^{14} \mathrm{C}$ content.

As illustrated in Figure 6, a considerable scatter in the final pMC results of the ablation zone samples is evident, which appears to be partly introduced by some outliers. This may be due the following reasons: 1) laboratory contamination by both fossil and modern carbon (note that the processing blank variability does not formally explain the observed outliers); 2) incomplete removal of carbonate particles, leading to extremely low pMC values for some samples; 3) substantial contribution of already "old" organic carbon (e.g. by soil dust deposition); and 4) intrusion of modern or younger carbon through snow deposited into crevasses upstream from the sampling sites. The first 2 effects may be minimized in future measurements by more refined procedures. Points 3 and 4 impose a principal limitation of the method. Additional measurements on the ice or meltwater may allow us to sort out such unreliable samples in the future. Extraordinarly high soil dust levels could indicate "old" organic carbon, whereas samples that experienced a contribution of modern snow or meltwater may be sorted out by tritium and ${ }^{210} \mathrm{~Pb}$ analyses or by traces of blue (bubble-free) ice. We have measured tritium and ${ }^{210} \mathrm{~Pb}$ on ice from our sampling sites, with negative results concerning any contamination by modern material. However, these measurements were not repeated on the ice samples processed for POC.

The statistical method used to further evaluate the present results should not be sensitive to these outliers, but should yield the "typical" pMC value, which is representative for the true sample age. Additionally, the measurement uncertainties as given in Table 2 are too small to explain the scatter 


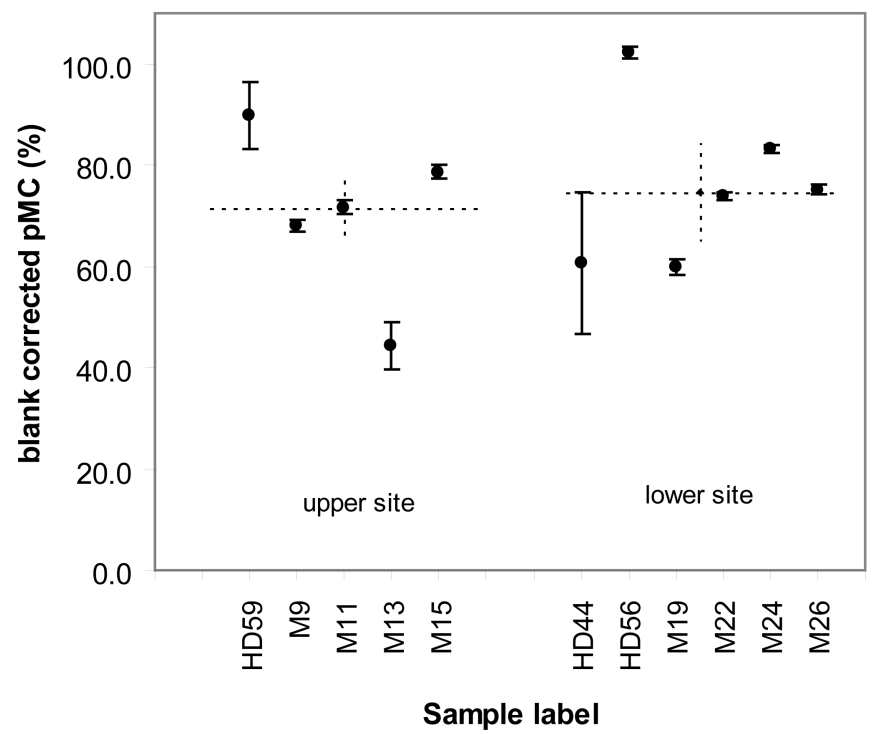

Figure 6 Overview on the variability of pMC values of POC in glacier ice measured for 2 sampling sites at the ablation zone of Grenzgletscher (Gornergletscher). The dashed crosses indicate the median pMC levels for the individual sites.

in the data, even for the samples that are not apparent outliers. Thus, the raw measurement uncertainties cannot be used to calculate weighted averages. Two simple methods are popular for handling data where outliers are expected: first, apparent outliers are rejected and mean values of the remaining data are used. The results for HD56 (modern) and M13 (44 pMC) appear to be outliers. Second, the median of the data can be used instead of the arithmetic average. Table 3 presents the results obtained with the 2 statistical methods. The uncertainty of the median was calculated using the method of Müller (2000). In our case, the results of the 2 statistical methods agree. The 2 sampling sites appear indistinguishable at the present measurement precision. Thus, we decided to combine the data from both sampling sites into 1 data set. We think that the most reliable method for evaluating this data is to take the median value of $73.9 \pm 5.6 \mathrm{pMC}$.

Table 3 Evaluation of mean and median pMC values for POC from Gornergletscher ice samples.

\begin{tabular}{llll}
\hline & $\begin{array}{l}\text { Upper site } \\
(\mathrm{pMC})\end{array}$ & $\begin{array}{l}\text { Lower site } \\
(\mathrm{pMC})\end{array}$ & $\begin{array}{l}\text { Site mean } \\
(\mathrm{pMC})\end{array}$ \\
\hline Arithmetic average with outlier(s) rejected & $77.0 \pm 4.8$ & $70.5 \pm 4.5$ & $73.4 \pm 3.3$ \\
Median, including outliers & $71.7 \pm 6.5$ & $74.6 \pm 9.7$ & $73.9 \pm 5.6$ \\
\hline
\end{tabular}

However, the combined data set $(n=11)$ is now large enough for more sophisticated uncertainty analysis. The yet unexplained uncertainty component in the data can be determined by adjusting its assumed value until a reduced $\chi^{2}$ equal to 1 is achieved. If all 11 samples are used, this additional uncertainty is $\pm 15.0 \mathrm{pMC}$, leading to a weighted average of $73.9 \pm 4.7 \mathrm{pMC}$. Both HD56 and M13 deviate from the weighted average by $1.9 \sigma$, whereas all other samples agree within $1 \sigma$. This supports our intuitive judgment that these 2 samples are outliers. Without these 2 samples, the additional uncertainty component is $\pm 8.3 \mathrm{pMC}$, resulting in a weighted average of $73.8 \pm 3.0 \mathrm{pMC}$. 
In our opinion, the most accurate value of the Grenzgletscher ice in the area of the 2 ice pits is $73.9 \pm$ $5.6 \mathrm{pMC}$. This corresponds to a calibrated age of $2100 \mathrm{BC}$ to AD 900 at a $95.4 \%$ confidence level, which is in broad agreement with the glaciological picture. At the current measurement precision, the wiggles of the calibration curve yield only a minor contribution to the uncertainty.

\section{DISCUSSION}

We developed and tested a system dedicated to AMS ${ }^{14} \mathrm{C}$ analyses of POC amounts in the range of 10-100 $\mu \mathrm{g} \mathrm{C}$ per $\mathrm{kg}$ of ice as contained in high alpine snow and non-temperated glacier ice. Combustion yields $\mathrm{CO}_{2}$ amounts down to $\sim 20 \mu \mathrm{g} \mathrm{C}$ for the filtrated POC and down to $\sim 5 \mu \mathrm{g} \mathrm{C}$ for the filtration blanks, which can be analyzed for ${ }^{14} \mathrm{C}$ at a typical precision of $1-3 \%$. A much larger contribution to the total uncertainty is introduced by the reproducibility of the filter blanks, leading to an uncertainty of up to $23 \%$ for the blank-corrected result of the smallest samples.

Improvements to the sample preparation technique should concentrate on further minimizing the amount and variability of the carbon background introduced during meltwater processing. In this context, attempts will be made to detach the collected particles from a suitable filter medium. This would allow for the processing of a larger amount of meltwater by using a smaller filter, which should greatly reduce the contamination level.

Test samples from the non-temperated ablation zone of Grenzgletscher showed a surprisingly large scatter in the pMC values, which makes it evident that at present a single ${ }^{14} \mathrm{C}$ date of glacial POC seems to have limited significance. This observation calls for a set of several measurements on the same ice body to achieve a reliable evaluation in terms of age. This strategy will be taken into account in future measurements by dividing the meltwater of 1 ice sample into aliquots of the smallest size still suitable for reliable ${ }^{14} \mathrm{C}$ determination. Especially in the case of ice samples from nontemperated ablation zones, a full chemical and radiochemical characterization of the ice samples appears to be mandatory in order to identify unreliable results. Finally, selected ice samples of known age (e.g. by stratigraphical dating) will be analyzed to tackle the question of how well the ${ }^{14} \mathrm{C}$ age of POC represents the true age of the ice.

\section{ACKNOWLEDGMENTS}

We thank Edwin Pak $\left({ }^{14} \mathrm{C}\right.$ Radiometric Laboratory, Institut für Isotopenforschung und Kernphysik, Universität Wien) for the bulk combustion of IAEA C-3 cellulose. The work was partly funded by the EC projects ALP-IMP (EVK2-CT-2002-00148) and CARBOSOL (EVK2-2001-00067).

\section{REFERENCES}

Armbruster M. 2000. Stratigraphische Datierung hochalpiner Eisbohrkerne über die letzten 1000 Jahre [Master's thesis]. Heidelberg: Institut für Umweltphysik, Universität Heidelberg. In German.

Biegalski SR, Currie LA, Fletcher RA, Klouda GA, Weissenbök R. 1998. AMS and microprobe analysis of combusted particles in ice and snow. Radiocarbon 40(1):3-10.

Chýlek P, Srivastava V, Cahenzli L, Pinnick RG, Dod RL, Novakov T, Cook TL, Hinds BD. 1987. Aerosol and graphitic carbon content of snow. Journal of Geophysical Research 92:9801-9.

Eisen O, Nixdorf U, Keck L, Wagenbach D. 2003. Alpine ice cores and ground penetrating radar: combined investigations for glaciological and climatic interpretations of a cold Alpine ice body. Tellus B 55:1007-17. EPICA Community Members. 2004. Eight glacial cycles from an Antarctic ice core. Nature 429:623-8.

Goslar T, van der Knaap WO, Hicks S, Andri M, Czernik J, Goslar E, Räsänen S, Hyötylä H. 2005. Radiocarbon dating of modern peat profiles: pre- and post-bomb ${ }^{14} \mathrm{C}$ variations in the construction of age-depth models. Radiocarbon 47(1):115-34.

Haeberli W. 1975. Eistemperaturen in den Alpen. Zeitschrift für Gletscherkunde und Glazialgeologie 11/2:203-20. In German. 
Haeberli, W, Kääb A, Wagner S, Vonder Mühll D, Geissler P, Haas JN, Glatzel-Mattheier H, Wagenbach D. 1999. Pollen analysis and ${ }^{14} \mathrm{C}$ age of moss remains in a permafrost core recovered from the active rock glacier Murtel-Corvatsch, Swiss Alps: geomorphological and glaciological implications. Journal of Glaciology 45/149:1-8.

Hammer C, Mayewski PA, Peel D, Stuiver M. 1997. Preface. Journal of Geophysical Research 102: 26,315-6.

Landeskarte der Schweiz 1:25000: Zermatt [map]. 1995. Bundesamt für Landestopographie. Wabern, Switzerland.

Lal D, Jull AJT, Donahue DJ, Burtner D, Nishiizumi K. 1990. Polar ice ablation rates measured using in situ cosmogenic ${ }^{14} \mathrm{C}$. Nature 346:350-2.

Lal D, Jull AJT, Burr GS, Donahue DJ. 2000. On the characteristics of cosmogenic in situ ${ }^{14} \mathrm{C}$ in some GISP2 Holocene and late glacial ice samples. Nuclear Instruments and Methods in Physics Research B 172: 623-31.

Lal D, Jull AJT, Donahue DJ, Burr GS, Deck B, Jouzel J, Steig E. 2001. Record of cosmogenic in situ produced ${ }^{14} \mathrm{C}$ in Vostok and Taylor Dome ice samples: implications for strong role of wind ventilation processes. Journal of Geophysical Research 106:31,933-42.

Levin I, Hesshaimer V. 2000. Radiocarbon-a unique tracer of global carbon cycle dynamics. Radiocarbon 42(1):69-80.

Meese DA, Gow AJ, Alley RB, Zielinski GA, Grootes PM, Ram M, Taylor KC, Mayewski PA, Bolzan JF. 1997. The Greenland Ice Sheet Project 2 depth-age scale: methods and results. Journal of Geophysical Research 102:26,411-23.

Müller JW. 2000. Possible advantages of a robust evaluation of comparisons. Journal of Research of the $\mathrm{Na}$ tional Institute of Standards and Technology 105:5515.

Petit JR, Jouzel J, Raynaud D, Barkov NI, Barnola J-M, Basile I, Benders M, Chappellaz J, Davis M, Delayque G, Delmotte M, Kotlyakov VM, Legrand M, Lipenkov VY, Lorius C, Pépin L, Ritz C, Saltzman E, Stievenard M. 1999. Climate and atmospheric history of the past 420,000 years from the Vostok ice core, Antarctica. Nature 399:429-36.

Reeh N, Oerter H, Lettrguilly A, Miller H, Hubberten HW. 1991. A new, detailed ice-age oxygen-18 record from the ice sheet margin in central West Greenland. Palaeogeography, Palaeoclimatology, Palaeoecology (Global and Planetary Change Section) 90:373-83.

Renaud A. 1952. Observations on the surface movement and ablation of the Gorner Glacier (Switzerland). Journal of Glaciology 2/11:54-7.

Rom W, Brenninkmeijer CAM, Bronk Ramsey C, Kut- schera W, Priller A, Puchegger S, Röckmann T, Steier P. 2000. Methodological aspects of atmospheric ${ }^{14} \mathrm{CO}$ measurements with AMS. Nuclear Instruments and Methods in Physics Research B 172:530-6.

Rozanski K, Stichler W, Gonfiantini R, Scott EM, Beukens RP, Kromer B, van der Plicht J. 1992. The IAEA ${ }^{14} \mathrm{C}$ intercomparison exercise 1990. Radiocarbon 34(3):506-19.

Seinfeld JH. 1998. Atmospheric Chemistry and Physics: From Air Pollution to Climate Change. New York: John Wiley \& Sons. $1326 \mathrm{p}$.

Steier P, Dellinger F, Kutschera W, Rom W, Wild EM. 2004. Pushing the precision limit of ${ }^{14} \mathrm{C}$ measurements with AMS. Radiocarbon 46(2):969-78.

Stuiver M, Polach HA. 1977. Discussion: reporting of ${ }^{14} \mathrm{C}$ data. Radiocarbon 19(3):355-63.

Szidat S, Jenk TM, Gäggeler HW, Synal HA, Hajdas I, Bonani G, Saurer M. 2004. THEODORE, a two-step heating system for the EC/OC determination of radiocarbon $\left({ }^{14} \mathrm{C}\right)$ in the environment. Nuclear Instruments and Methods in Physics Research B 223-224:829-36.

Thompson LG, Davis ME, Mosley-Thompson E, Sowers TA, Henderson KA, Zagorodnov VS, Lin P-N, Mikhalenko VN, Campen RK, Bolzan JF, Cole-Dai J, Francou B. 1998. A 25,000-year tropical climate history from Bolivian ice cores. Science 282:1858-64.

Thompson LG, Mosley-Thompson E, Davis ME, Henderson KA, Brecher HH, Zagorodnov VS, Mashiotta TA, Lin P-N, Mikhalenko VN, Hardy DR, Beer J. 2002. Kilimanjaro ice core records: evidence of Holocene climate change in tropical Africa. Science 298: 589-93.

Van Roijen JJ, van der Borg K, de Jong AFM, Oerlemans J. 1995. Ages and ablation rates from ${ }^{14} \mathrm{C}$ measurements on Antarctic ice. Annals of Glaciology 21:13943.

Vandeputte K, Moens L, Dams R, van der Plicht J. 1998. Study of the ${ }^{14} \mathrm{C}$-contamination potential of C impurities in $\mathrm{CuO}$ and Fe. Radiocarbon 40(1):103-10.

Vogel JS, Southon JR, Nelson DE, Brown TA. 1984. Performance of catalytically condensed carbon for use in accelerator mass spectrometry. Nuclear Instruments and Methods in Physics Research B 5:289-93.

Wagenbach D. 1989. Environmental records in alpine glaciers and ice sheets. In: Oeschger H, Langway CC, editors. The Environmental Record in Glaciers and Ice Sheets. Dahlem Konferenzen. Chichester: John Wiley \& Sons Limited. p 69-83.

Weissenbök R, Currie LA, Gröllert C, Kutschera W, Marolf J, Priller A, Puxbaum H, Rom W, Steier P. 2000. Accelerator mass spectrometry analysis of non-soluble carbon in aerosol particles from high alpine snow (Mt. Sonnblick, Austria). Radiocarbon 42(2):285-94. 